\title{
Rancang Bangun Alat Uji Gaya Dorong (Trust Force) Motor Brushless
}

\author{
Randis $^{1)}$, Ida Bagus Dharmawan'), Syahruddin ${ }^{3)}$ \\ ${ }^{1,2)}$ Teknik Mesin Alat Berat, Politeknik Negeri Balikpapan \\ e-mail : randis@poltekba.ac.id
}

\begin{abstract}
The aim of this research is to design and make testing tool of trust force brushless motor and propeller in the use of Unmanned Aerial Vehicle (UAV). The testing tool system of trust force created in this study make use of Arduino Uno Atmega 328 as its microcontroller. This tool is equipped with a load cell that serves to measure the amount of thrust force generated by the combination of brushless motors and propellers when rotating. The load cell used is load cell $5 \mathrm{~kg}$ which is connected to the HX 711 module that serves to convert the changes that occur in the measured load cell in the change of resistance and convert it into the voltage across the circuit. There are 2 pieces of microcontroller, one microcontroller is used to set the magnitude RPM of brushless motor and another microcontroller serves to process input signals from load cell and HX 711 which will be passed into output in the form of gravity data through serial monitor on pc / laptop. This research resulted in the design testing tool of trust force which is able to test the thrust force of a combination of brushless motors and propellers up to a maximum of $5 \mathrm{~kg}$ with the use of brushless motors and propellers can be changed or varied the output is the amount of gravity data through the serial monitor and can be plotted in the form of tables or graphs.
\end{abstract}

Keyword : Unmanned Aerial Vehicle (UAV), trust force, brushless motor, propeller

\begin{abstract}
Abstrak
Penelitian ini bertujuan untuk merancang dan membuat alat uji gaya dorong dari kombinasi motor brushless dan baling-baling pada penggunaan Unmanned Aerial Vehicle (UAV). Sistem alat uji gaya dorong yang dibuat pada penelitian ini memanfaatkan Arduino Uno Atmega 328 sebagai mikrokontrollernya. Alat ini dilengkapi dengan load cell yang berfungsi untuk mengukur besarnya gaya dorong yang dihasilkan oleh kombinasi motor brushless dan baling-baling saat berputar. Load cell yang digunakan adalah load cell $5 \mathrm{~kg}$ yang dihubungkan dengan modul $H x 711$ yang berfungsi untuk mengkonversi perubahan load cell yang terukur dalam perubahan resistensi dan mengkonversinya kedalam besaran tegangan melalui rangkaian yang ada. Terdapat 2 buah mikrokontroller dimana satu mikrokontroller digunakan untuk mengatur besarnya RPM motor brushless dan mikrokontroller lainya berfungsi untuk mengolah sinyal masukan dari load cell dan Hx 711 yang akan diteruskan menjadi output berupa data gaya berat melalaui serial monitor pada pc/laptop. Penelian ini menghasilkan rancangan alat uji gaya dorong yang mampu menguji gaya dorong dari kombinasi motor brushless dan baling-baling sampai maksimal $5 \mathrm{~kg}$ dengan penggunaaan motor brushless dan baling-baling yang dapat diganti-ganti atau divariasikan dengan output berupa data besaran gaya berat melalui serial monitor dan dapat di plot dalam bentuk table atau grafik.
\end{abstract}

Kata kunci : Unmanned Aerial Vehicle (UAV), gaya dorong, motor brushless, baling-baling 


\section{Pendahuluan}

Robot merupakan teknologi yang dikembangkan untuk membantu manusia dalam melaksanakan tugas tertentu, misalnya tugas yang membutuhkan kehatihatian tinggi, berisiko tinggi, tugas yang membutuhkan kekuatan besar, atau tugas yang monoton. Selain itu, juga bisa digunakan untuk tempat yang sulit dijangkau manusia atau medan yang berbahaya. Salah satu teknologi robot yang sedang dikembangkan oleh beberapa negara adalah robot terbang, baik di dalam bentuk pesawat atau helikopter dengan berbagai jenis. Robot terbang jenis helikopter ini digunakan untuk kebutuhan yang tidak bisa dijangkau oleh manusia seperti memonitor kemacetan, survai dan pemetaan, robot mata-mata, untuk dipantau bencana alam, untuk memantau kebakaran lahan, untuk menjamin peralatan pemadam kebakaran, media pencarian dan misi penyelamatan (SAR), untuk mengawal presiden dan memantau pembangunan gedung pada bidang insinyur sipil [1].

UAV (Unnmaned Aerial Vehicle) secara umum dapat diart ikan sebuah wahana udara jenis fixed-wing, rotarywing, ataupun pesawat yang mampu mengudara pada jalur yang ditentukan tanpa kendali langsung oleh pilot. Teknologi UAV sudah banyak di aplikasikan untuk pemantauan lingkungan dan keamanan, pengawasan meteorologi, riset cuaca, agrikultur, eksplorasi dan eksploitasi bahan-bahan mineral bahkan untuk kepent ingan militer [2].

Unmanned Aerial Vehicle (UAV) atau pesawat tanpa awak banyak mendapat perhatian dari berbagai kalangan karena dapat menggantikan peran pilot manusia sebagai sistem kendalinya. Hal tersebut menjadikan $U A V$ banyak dimanfaatkan untuk keperluan militer ataupun sipil [3]. Bentuk UAV yang pada umumnya berskala kecil membuatnya lebih aman untuk interaksi dekat, sehingga memungkinkan penerbangan melalui lingkungan terbatas.
Seiring perubahan zaman, pemanfaatan Unmanned Aerial Vehicle (UAV) atau pesawat tanpa awak sebagai robot udara robot terbang semakin berkembang, bukan hanya sebuah permainan dan seni menerbangkan pesawat tanpa awak namun digunakan juga untuk kegiatan pengintaian, pemetaan lokasi, pengambilan gambar dari atas udara baik yang bergerak (video) maupun yang tidak bergerak (foto), dan pemantauan lokasi korban bencana alam yang sulit dijangkau oleh kendaraan. Pemanfaatan pesawat tanpa awak sudah merambah diberbagai bidang diantaranya bidang militer, fotografi, sinematografi, geografi, dan berbagai bidang lainnya [4].

Unmanned Aerial Vehicle (UAV) atau pesawat tanpa awak makin dikembangkan untuk memudahkan pekerjaan manusia. Hal yang paling baru adalah pengembangan Unmanned Aerial Vehicle (UAV) atau pesawat tanpa awak sebagai wahana pemadam kebakaran dengan mengangkat APAR (Alat Pemadam Api Ringan) dengan menggunakan $U A V$ [5][6].

Pengantaran paket ketempat tujuan dengan menggunakan wahana Unmanned Aerial Vehicle $(U A V)$ atau pesawat tanpa awak yang terintegrasi dengan gps dan aplikasi di smartphone [7][8].

Pengunaan Unmanned Aerial Vehicle $(U A V)$ atau pesawat tanpa awak sebagai wahana pengiriman paket tentunya membutuhkan tenaga berupa gaya dorong (thrust force) yang besar guna mengangkat barang yang akan dikirim ke tempat tujuan dan menunjang tugas pengiriman paket sampai dengan selamat ke tempat tujuan.

Beberapa penelitian sebelumya menyatakan bahwa setiap motor dan baling-baling pada UAV memiliki tipe yang sama, maka cukup mengetes satu motor saja untuk menentukan dorong dan torsi yang dihasilkan [9]. Oleh karena itu penelitian ini dilakukan untuk merancang dan membuat sebuat alat uji gaya dorong motor dan baling-baling yang 
dipergunakan di Unmanned Aerial Vehicle $(U A V)$ sehingga tidak perlu menguji motor dan baling-baling dari robot terbang secara keseluruhan tapi cukup menguji satu saja namun sudah terwakili.

\section{Metoda Penelitian}

\subsection{Perancangan Sistem}

Rancangan penelitian yang dikembangkan untuk memperoleh lebih banyak data sehingga diharapkan hasil plot grafik yang tercipta dapat lebih baik. Perangkat Elektronik pada penelitian ini terdiri 2 yaitu: perangkat elektronik untuk load cell dan perangkat elektronik untuk motor brushless. Untuk perangkat elektronik load cell itu sendiri terdiri atas power, Arduino Uno Board, HX 711, dan Load Cell. Skema rangkaian ditunjukkan pada gambar 1 .

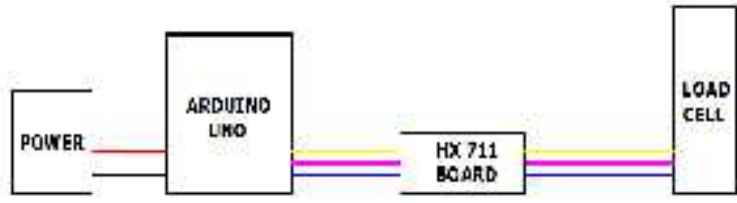

Gambar 1. Desain Rancangan (load cell)

Sedangkan untuk perangkat elektronik motor brushless itu sendiri terdiri dari motor brushless, ESC, Arduino uno board, potensio dan baterai lipo. Skema rangkaian ditunjukkan pada gambar 2 .

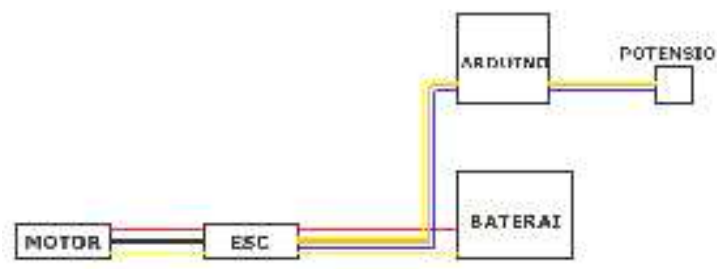

Gambar 2. Desain Rancangan (Motor Brushless)

\subsection{Peralatan Penelitian}

Pada penelitian ini digunakan alat berupa: Gerinda, bor tangan, tool box, obeng set dan kunci L. Sedangkan bahan yang digunakan yaitu: motor brushless, ESC, arduino uno, bateray lipo, load cell dan $H x 711$.

\subsection{Pemrograman}

Secara sederhana program yang disematkan kedalam board mikrokontroller dalam hail ini adalah arduino uno board, berfungsi untuk mengatur capaiaan keluaran/output yang kita harapkan. Mikrokontroller ini merupakan otak dari tool yang dibuat, sedangkan program yang dimasukkan merupakan inplementasi apa yang kita inginkan dapat terlaksana pada rangkaian sistem.

Sketch program pada diperlihatkan pada gambar 3 .

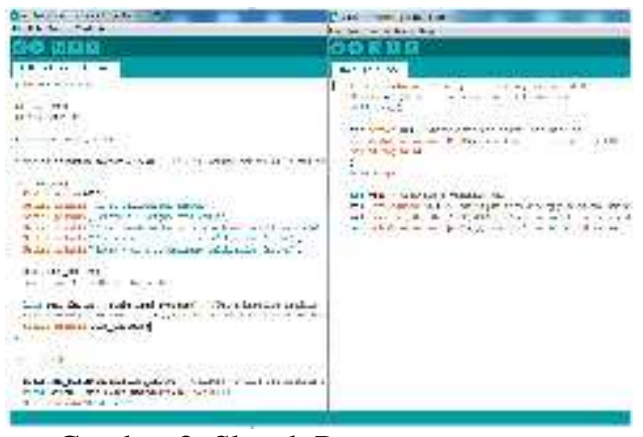

Gambar 3. Sketch Program

\subsection{Langkah Penelitian}

Pembuatan alat dimulai dari persiapan kemudian perancangan. Perancangan ini disesuaikan dengan rancangan awal yang sesuai untuk mengukur dan dapat mewakili gaya dorong yang akan diukur dan dihitung.

Setelah memenuhi syarat, maka alat pengujian akan dibuat sesuai rancangan yang telah dibuat dan dilakukan pemasangan rangkaian elektronik. Setelah alat selesai, barulah dilanjutkan pengujian dan simulasi dilanjutkan dengan pengambilan data dan perhitungan serta plot grafik hasil pengujian alat tersebut.

\section{Hasil Penelitian}

\subsection{Implementasi Sistem Electronic}

Baterai lipo (Lithium Polymer) menyuplai listrik ke ESC yang kemudian diteruskan ke motor brushless. Arduino bertindak sebagai mikrokontroller yang memperoleh power dari baterai sendiri dengan tegangan 9 volt sementara potensio dan ESC sebagai komponen untuk mengatur besarnya kecepatan yang dihasilkan oleh motor brushless. 
Penggunaan komponen ini dimaksudkan untuk meperoleh hasil data yang lebih banyak dalam satuan waktu.

Sedangkan pada rangkaian load cell terdiri dari $H X 711$ board yang berfungsi untuk mengkonversi perubahan load cell yang terukur dalam perubahan resistensi dan mengkonversinya kedalam besaran tegangan melalui rangkaian sehingga dapat dibaca oleh mikrokontroller, sedangkan arduino uno bertindak sebagai mikrokontroller. Digunakan dua buah board arduino uno untuk memudahkan listing program juga dapat memudahkan dalam proses kalibrasi load cell pada penelitian ini.

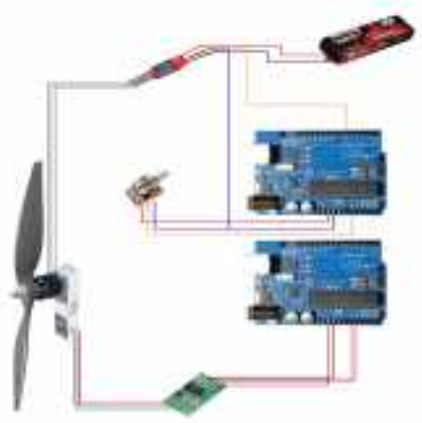

Gambar 4. Rangkaian Sistem Electrical

Penggunaan alat ukur gaya dorong (trust force) menggunakan load cell, load cell ini diikat dengan menggunakan support yang terbuat dari besi strip. Motor brushless akan mendorong load cell sehingga timbul tekanan pada laod cell dan menghasilkan sinyal keluaran yang diperkuat oleh $h x 7111$ board yang kemudian diolah oleh board arduino uno sebagai mikrokontrolller. Setiap data terekam oleh serial monitor pada arduino, selanjutnya data ini di olah di program exel yang selanjutnya dikembangkan dalam bentuk grafik.

\subsection{Implementasi Sistem Mekanikal}

Pada ujung load cell terpasang sebuah motor brushless yang telah terpasang baling-baling di ujungnya, panjang diameter baling-baling ini akan divariasikan sehingga akan terlihat pengaruhnya terhadap gaya dorong (trust force) yang dihasilkan, perbedaan mendasar dari rancangan desain sebelumnya bahwa rancangan sebelumnya hanya mampu mengukur gaya dorong akhir dari motor brushlesh akan tetapi pada rancangan actual ini, gaya dorong yang terjadi dapat direkam setiap detiknya atau persatuan waktu yang kita inginkan, dengan alat atau rangkaian tambahan, juga dapat direkam besarnya gaya dorong persatauan putaran motor.

Desain rancangan dan hasil implementasi mekanikal ditunjukkan pada gambar di bawah ini.
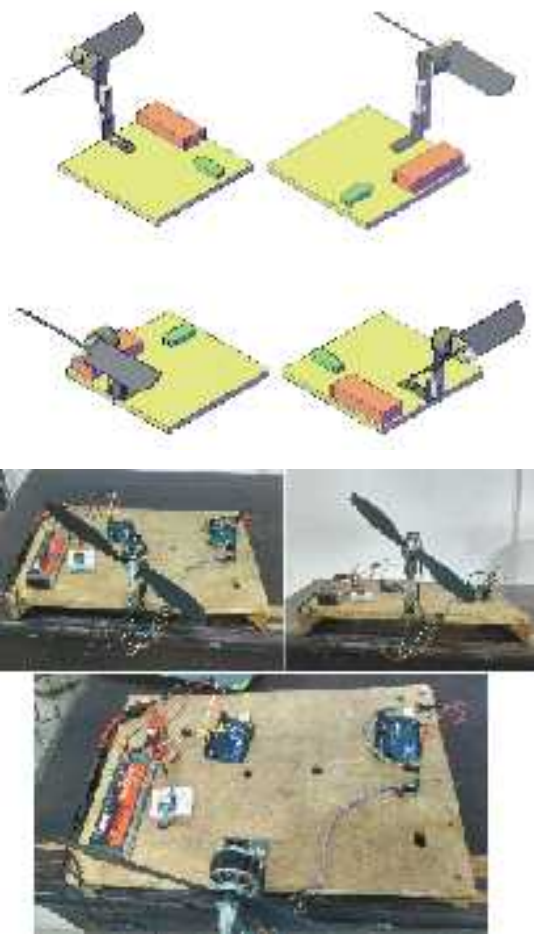

Gambar 5. Rangkaian Sistem Mekanikal

\subsection{Monitoring Sistem}

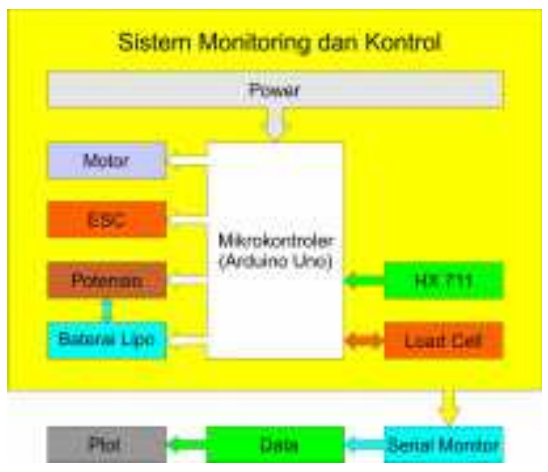

Gambar 6. Rangkaian Sistem Mekanikal 
Sistem monitoring yang dibuat berbasis mikrokontroller Arduino Uno dengan IC ATmega328. Arduino Uno ini merupakan mikrokontroller bertindak sebagai otak dari sistem yang akan mengontrol kerja sistem. Arduino akan mengambil data dari perangkat load cell hasil dari gaya dorong yang dihasilkan oleh motor dan baling-baling yang berputar. Sistem monitoring dan kontrol ditunjukkan pada gambar 6. Monitoring dilakukan melalui serial monitor dari pc/laptop hasil data yang diperoleh di plot dalam bentuk grafik.

\subsection{Pengujian Sistem}

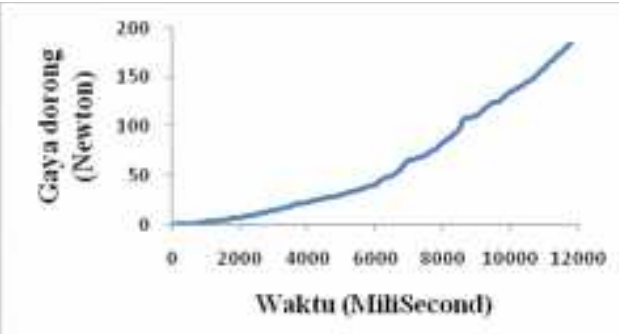

Gambar 7. Grafik gaya dorong vs Waktu

Pengujian alat dilakukan dengan menggunakan motor brushless jenis $\mathrm{T}$ Motor $750 \mathrm{Kv}$ dengan menggunakan baling-baling genfan $10 \times 4.5 \mathrm{cw}$. Hasil plot grafik ditunjukkan pada gambar 7, dengan membandingkan gaya dorong yang dihasilkan dengan waktu. Pada grafik yang dihasilkan menunjukkan peningkatan gaya dorong yang terjadi dengan bertambahya waktu, hal ini dengan melakukan pemutaran potensio secara perlahan sampai batas maksimum potensio. Data yang diperoleh sekitar 188 data dalam kurung waktu kurang dari 12 detik.

\section{Kesimpulan}

Dari hasil penelitian diperoleh beberapa kesimpulan sebagai berikut:

a. Sistem electronic menggunakan 2 buah mikrokontroller untuk memudahkan listing program dan proses kalibrasi pada load cell.

b. Sistem mekanikal yang dibuat mengikuti desain rancangan yang telah dibuat di software. c. Sistem monitoring dan control dilakukan melalui serial monitor hasil data yang diperoleh diplot dalam bentuk grafik.

d. Plot grafik yang dihasilkan menunjukkan peningkatan gaya dorong yang dihasilkan seiring dengan bertambahnya waktu dengan memutar potensio.

\section{Saran}

Penelitian lanjutan dapat dilakukan dengan mengembangkan alat ini dengan menambahkan sensor tegangan, sensor arus, sensor putaran motor, dan data dapat lansung tersimpan dalam exel.

\section{Daftar Pustaka}

[1] Sudarma, Made, IB Alit Swamardika, and Adinata Mas Pratama. "Design of Quadcopter Robot as a Disaster Environment Remote Monitor." International Journal of Electrical and Computer Engineering 6.1 (2016): 188.

[2] Unmanned Air Vehicle. http://www.tc.gc.ca/ civilaviation/general/rec avi/Brochures/uav. htm. 15 Agustus 2017

[3] Almurib, Haider AF, Premeela T. Nathan, and T. Nandha Kumar. "Control and path planning of quadrotor aerial vehicles for search and rescue." SICE Annual Conference (SICE), 2011 Proceedings of. IEEE, 2011.

[4] Asrul. Sistem Kendali Posisi Dan Ketinggian Terbang Pesawat Quadcopter. Tesis, Teknik Komputer, Kendali, Dan Elektronika Universitas Hasanuddin Makassar (2014).

[5] Qin, Hailong, et al. "Design and implementation of an unmanned aerial vehicle for autonomous firefighting missions." Control and Automation (ICCA), 2016 12th IEEE International Conference on. IEEE, 2016.

[6] Remington, Raquel. "Multi-Purpose Aerial Drone for Bridge Inspection and Fire Extinguishing." Unpublished Thesis). Florida International University. Retrieved April 10 (2014): 2016.

[7] Choi, Youngmin, and Paul M. Schonfeld. 
Optimization of Multi-package Drone Deliveries Considering Battery Capacity. No. 17-05769. 2017.

[8] Kim, Yun Chul, et al. "Strategy and Further Researches for Operation of Drone Logistics System." 한국경영과학회 학술대회논문집 (2016): 2376-2387.

[9] Syam R, Mappaita A, et al. " Simple Design of VTOL Hexacopter for Simple Navigation." International Journal on Smart Material and Mechatronics. IJSMM,2017. 